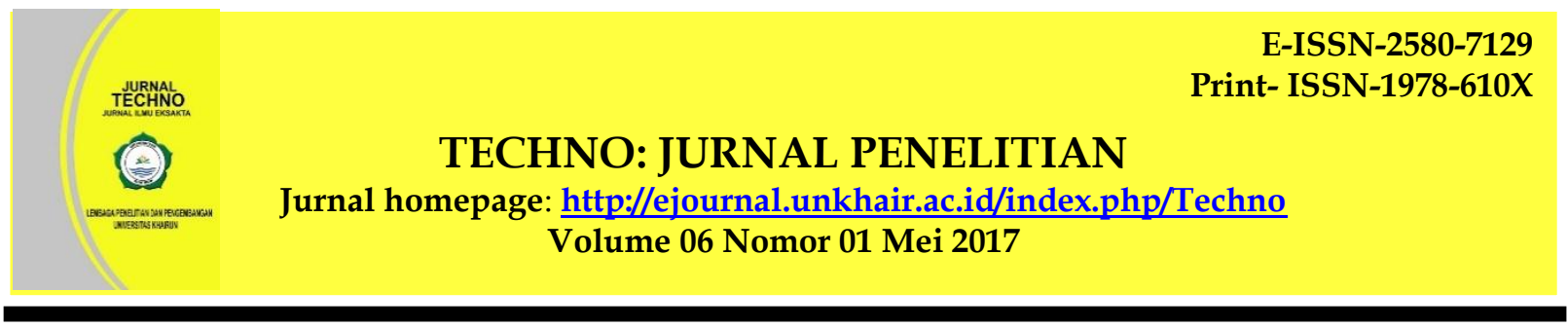

\title{
Kapasitas Lentur Balok Beton dengan Bahan Tambah Abu Vulkanik Gunung Gamalama
}

\author{
Mufti Amir Sultan ${ }^{* 1}$, Imran $^{1}$, Siswoko ${ }^{2}$ \\ 1Program Studi Teknik Sipil, Fakultas Teknik Universitas Khairun, Ternate \\ ${ }^{2}$ Mahasiswa Teknik Sipil, Fakultas Teknik Universitas Khairun, Ternate \\ *Corresponding authors: e-mail: muftiamirsultan.unkhair@gmail.com
}

Manuscript received: 11-02-2017 Revision accepted: 16-04-2017

\begin{abstract}
Abstrak
Beton merupakan bahan konstruksi yang mempunyai peranan yang semakin luas seiring dengan laju pembangunan saat ini. Dalam pelaksanaan beton di lapangan kadang digunakan bahan tambah (admixture) untuk memperbaiki sifat atau kinerjia beton. Bahan tambah dapat berupa bahan kimia, serat dan bahan buangan non kimia yang dicampurkan dengan perbandingan tertentu. Usaha yang dilakukan untuk meningkatkan kinerja dan durabilitas beton melalui penggunaan berbagai jenis bahan tambah seperti fume silica, slag, fly ash ataupun natural pozzolan (volcano ash). Bahan tambah yang digunakan yaitu Abu Vulkanik Gamalam (AVG). Penelitiana ini bertujuan untuk mengetahui pengaruh AVG terhadap kuat lentur beton. Benda uji yang digunakan adala balok berukuran $(15 \times 15 \times 60) \mathrm{cm}$, Mutu beton K-225 dengan variasi penambahan AVG 20\% terhadap berat semen. Pengujian kuat lentur dilakukan pada umur beton 28 hari. Hasil penelitian diperoleh bahwa pada beton dengan bahan tambah AVG kuat lentur balok sebesar $38,509 \mathrm{~kg} / \mathrm{cm}^{2}$, sedangkan untuk beton tanpa campuran Abu Vulkanik Gamalama (AVG) sebesar 29,448 kg/ $\mathrm{cm}^{2}$ atau terjadi kenaikan kuat lentur sebesar 23,53\%
\end{abstract}

Kata kunci: abu vulkanik, AVG, kuat lentur, beton.

\begin{abstract}
Concrete is a construction material where its role is broader along with the current development. In field, concrete is sometimes used as an admixture to improve the nature or performance of the concrete. Admixture can be in form of chemical material, fiber and non-chemical waste material that mix with certain ratio. Efforts conducted to improve the performance and durability of concrete through the use of various types of admixture, such as fume silica, slag, fly ash or natural pozzolan (volcano ash). Admixture used was Gamalama Volcanic Ash (AVG). The research aimed to find out the influence of AVG on concrete flexural strength. Testing materials used were concretes with size of $(15 \times 15 \times 60) \mathrm{cm}, \mathrm{K}-$ 225 concrete quality with variation of AVG addition of $20 \%$ against the cement weight. Flexural strength test was conducted on 28 days concrete. The research result found that concrete with admixture of AVG the concrete flexural strength was $38.509 \mathrm{~kg} / \mathrm{cm}^{2}$, whereas for concrete without Gamalama Volcanc Ash (AVG) mixture was $29.448 \mathrm{~kg} / \mathrm{cm}^{2}$ or an increase in the flexural strength of $23.53 \%$.
\end{abstract}

Keywords: volcanic ash, AVG, flexural strength, concrete. 


\section{PENDAHULUAN}

Beton merupakan bahan konstruksi yang umum dalam konstruksi. Beton banyak digunakan untuk bahan pembentuk struktur baik sebagai upper structure maupun sub structure. Kemajuan teknologi beton memungkinkan untuk di bangunnya struktur-struktur besar berupa gedunggedung bertingkat maupun sarana transportasi misalnya jembatan dengan bentang panjang, lapisan perkerasan untuk jalan dan untuk lapangan udara.

Beton merupakan bahan konstruksi yang mempunyai peranan yang semakin luas seiring dengan laju pembangunan saat ini. Beton didapat dari pencampuran bahan-bahan agregat halus dan kasar berupa pasir, batu pecah, dengan menambahkan secukupnya bahan perekat semen, dan air sebagai bahan pembantu guna keperluan reaksi kimia selama proses pengerasan dan perawatan beton berlangsung dan juga bahan tambah (admixture). Bahan tambah ini dapat berupa bahan kimia, serat dan bahan buangan non kimia yang dicampurkan dengan perbandingan tertentu. Usaha yang dilakukan untuk meningkatkan kinerja dan durabilitas beton melalui penggunaan berbagai jenis bahan tambah seperti fume silica, slag, flya ash ataupun natural pozzolan (volcano ash).

Abu vulkanik merupakan salah satu alternatif bahan pengganti semen, yang telah banyak diteliti dan bahwa dapat bermanfaat dalam campuran beton. Salah satunya (Olawuyi and Olusola 2010) meneliti pemanfaatan abu vulkanik untuk pembuatan beton mutu tinggi, dari hasil penelitian menyatakan bahwa penambahan abu vulkanik sebagai campuran pada beton baik yang berukuran 100 mesh maupun mikro size dapat menghasilkan beton mutu tinggi yang ringan dengan kepadatan tinggi. Selanjutnya (Yasin, Awwad et al. 2012) meneliti penggunan abu vulknik dalam campuran beton, hasil analisis menunjukkan bahwa mengganti agregat halus sebesar $20 \%$ abu vulkanik akan meningkatkan kuat tekan beton sebesar $10 \%$ untuk abu vulkanik coklat dan 15\% untuk abu vulkanik kuning. (Kamang, Oyemogum et al. 2013) meneliti penggunaan metakoalin dan abu vulkanik dalam campuran portland semen, hasil penelitian merekomendasikan bahwa metakoalin dan abu vulkanik dapat dicampur dalam jumlah hingga $30 \%$ setiap berat semen.

Abu vulkanik merupakan material yang dikeluarkan dari perut bumi ketika terjadi erupsi gunung berapi serta dapat terangkut oleh angin dan air hingga jarak berkilometer dari lokasi gunung berapi berada. Abu vulkanik menjadi isu lingkungan yang penting karena jumlahnya yang cukup banyak dan menganggu keseimbangan lingkungan. Abu vulkanik merupakan material piroklastik yang sangat halus namun memiliki ciri bentuk yang beragam. Dalam bidang teknik, penggunaan abu vulkanik sebagai bahan tambah masih sangat sedikit dan terbatas, sedangkan gunung berapi yang masih aktif mengeluarkan abu vulkanik setiap tahunnya sangat banyak.

Maluku utara memiliki 5 gunung berapi aktif, gunung-gunung tersebut memiliki potensi erupsi, salah satunya adalah Gunung Gamalama yang merupakan gunung berapi terletak di Pulau Ternate. Gunung Gamalama erupsi terakhir pada tanggal 03 Agustus 2016 walaupun tidak menimbulkan kerusakan dan korban jiwa namun menyisakan banyak debu vulkanik.

Dari penjelasan diatas, bahwa dengan penggunaan fly ash dalam hal ini abu vulkanik dalam campuran beton dapat meningkatkan kinerjia dan durabilitas beton, serta ketersediaan abu vulkanik di Maluku Utara yang belum dimanfaatkan sebagai material konstruksi. 
SULTAN dkk. ABU VULKANIK, AVG, KUAT LENTUR, BETON.

\section{METODE PENELITIAN}

\section{Waktu dan Tempat Penelitian}

Tahap penelitian diawali dengan persiapan alat sekaligus proses pengujian bahan. Penelitian ini merupakan studi eksperimental yang dilakukan di Laboratorium Struktur dan Bahan Jurusan Teknik Sipil Universitas Khairun.

\section{Bahan dan Peralatan}

Bahan yang digunakan pada campuran beton adalah sebagai berikut :

a. Semen, semen sebagai bahan pengikat adukan beton digunakan semen portland tipe I.

b. Agregat halus, agregat halus yang digunakan adalah pasir yang diambil dari quarry yang berlokasi di kelurahan Togafo.

c. Agregat kasar, agregat kasar yang digunakan adalah batu pecah yang diambil dari lokasi pemecah batu di Kelurahan Tubo.

d. Air, air yang digunakan untuk pencampuran adalah air yang berasal dari PDAM Ternate.

\section{Benda uji}

Benda uji terbagi atas dua tipe :

a. Benda uji balok dengan ukuran $15 \mathrm{~cm} \times 15 \mathrm{~cm} \times 60 \mathrm{~cm}$, potongan melintang $15 \times 15 \mathrm{~cm}$, digunakan tulangan tarik $2 \square 10$ untuk pengujian kuat lentur

b. Benda uji silinder dengan ukuran $15 \mathrm{~cm}$ x $30 \mathrm{~cm}$ untuk pengujian kuat tekan dan elatisitas. Rincian benda uji seperti pada tabel 1 .

Tabel 1. Variasi benda uji

\begin{tabular}{clcc}
\hline No & \multicolumn{1}{c}{ Benda Uji } & $\begin{array}{c}\text { Jumlah } \\
\text { (bh) }\end{array}$ & $\begin{array}{c}\text { Kadar AVG } \\
\text { (\%) }\end{array}$ \\
\hline 1 & Balok Normal $\left(\mathrm{B}_{\mathrm{N}}\right)$ & 2 & 0 \\
2 & Balok AVG $\left(\mathrm{B}_{\mathrm{AVG}}\right)$ & 2 & 20 \\
3 & Silinder Normal $\left(\mathrm{S}_{\mathrm{N}}\right)$ & 5 & 0 \\
4 & Silinder AVG $\left(\mathrm{S}_{\mathrm{AVG}}\right)$ & 5 & 20 \\
\hline
\end{tabular}

\section{Prosedur Penelitian}

Sebelum dilakukan pengecoran benda uji, bahan-bahan penyusun benda uji seperti agregat halus dan agregat kasar dilakukan pemeriksaan properties di laboratorium. Dalam penelitian ini direncanakan campuran mutu beton K 225. Penentuan komposisi campuran menggunakan metode Standar Nasional Indonesia (SNI). Benda uji diberikan kode kemudian beton dirawat dengan cara perendaman dengan air tawar sampai waktu pengujian kekuatan beton yaitu selama 28 hari.

\section{Pengujian Lentur}

Benda uji diletakan pada tumpuan sederhan, dial dipasang pada bagian bawah balok tepat pada jarak $1 / 2$ dari panjang bentang bersih balok dan masing-masing kearah kiri dan kanan dari tengah bentang tepat di bawah titik point load. Pembebanan menggunakan sistem two point load. Skema model pengujian seperti pada gambar 1. 


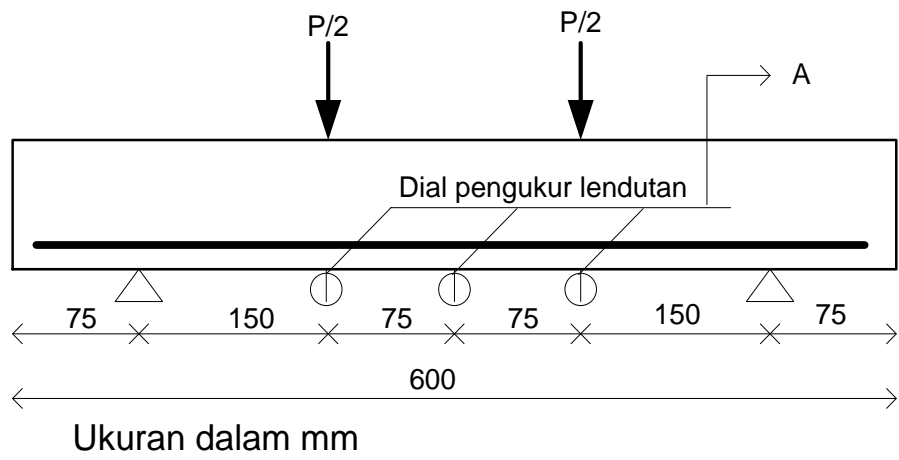

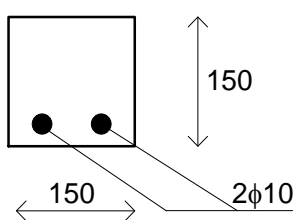

Pot. A-A

Gambar 1. Setup Pengujian Balok

\section{HASIL DAN PEMBAHASAN}

\section{Properties agregat}

Tabel 2 menunjukkan hasil pengujian agregat halus, di mana untuk pengujian kadar air 3,1\%, kadar lumpur 2,0\%, kondisi lepas 1,60\%, kondisi padat 1,62\%, berat jenis kering oven 2,61 \%, berat jenis semu 2,76\% dan penyerapan air 2,04\%. Ini memperlihatkan bahwa properties agregat halus telah memenuhi spesifikasi, kecuali penyerapan air yang tidak sesuai spesifikasi sehingga pada saat memulai pembuatan benda uji agregat yang digunakan pada kondisi SSD agar penyerapan air tidak terlalu banyak.

Tabel 2. Rekapitulasi Hasil Pengujian Agregat Halus

\begin{tabular}{clcc}
\hline No & \multicolumn{1}{c}{ Properties } & Hasil Pengujian & Spesifikasi \\
\hline 1 & Kadar air & $3,1 \%$ & $3 \%-5 \%$ \\
2 & Kadar lumpur & $2,0 \%$ & $0,2 \%-5,0 \%$ \\
3 & Berat volume (lepas) & 1,60 & $1,40-1,90$ \\
4 & Berat volume (padat) & 1,62 & $1,40-1,90$ \\
5 & Berat jenis kering oven & 2,61 & $1,60-3,20$ \\
6 & Berat jenis SSD & 2,67 & $1,60-3,20$ \\
7 & Berat jenis semu & 2,76 & $1,60-3,20$ \\
8 & Penyerapan air & 2,04 & $0,2-2,0$ \\
\hline
\end{tabular}

Sumber: hasil pengujian, 2016

Tabel 3. Rekapitulasi Hasil Pengujian Agregat Kasar

\begin{tabular}{llcc}
\hline No & \multicolumn{1}{c}{ Properties } & Hasil Pengujian & Spesifikasi \\
\hline 1 & Kadar air & $0,5 \%$ & $0,5 \%-2,0 \%$ \\
2 & Kadar lumpur & $1,1 \%$ & $0,2 \%-1,0 \%$ \\
3 & Berat volume (lepas) & 1,70 & $1,60-1,90$ \\
4 & Berat volume (padat) & 1,80 & $1,60-1,90$ \\
5 & Berat jenis kering oven & 2,29 & $1,60-3,20$ \\
6 & Berat jenis SSD & 2,32 & $1,60-3,20$ \\
7 & Berat jenis semu & 2,35 & $1,60-3,20$ \\
8 & Penyerapan air & 1,17 & $0,2-2,0$ \\
9 & Keausan & $24,05 \%$ & $15 \%-50 \%$ \\
\hline
\end{tabular}


Tabel 3 menunjukkan hasil pengujian properties agregat kasar di mana :pengujian kadar air $0,5 \%$, kadar lumpur 1,1\%, kondisi lepas 1,8 kg/ltr, kondisi padat 1,7 kg/ltr, berat jenis kering oven $2,29 \%$, berat jenis semu $2,35 \%$ dan keausan agregat $24 \%$. Ini memperlihatkan bahwa properties agregat kasar telah memenuhi spesifikasi, kecual kadar lumpur yang tidak sesuai dengan spesifikasi sehingga sebelum material agregat kasar digunakan perlu dicuci guna untuk menghilangkan lumpur yang ada pada agregat kasar.

\section{Komposisi Campuran Beton (JMF)}

Tabel 4. Kasar Komposisi Rencana Campuran $1 \mathrm{~m}^{3}$ Beton

\begin{tabular}{|c|c|c|}
\hline Material & Berat per $\mathrm{m}^{3}$ beton $(\mathrm{kg})$ & $\begin{array}{c}\text { Rasio terhadap } \\
\text { semen }\end{array}$ \\
\hline Semen & 385,417 & 1 \\
\hline Batu pecah & 608,250 & 1,578 \\
\hline pasir & $1.081,333$ & 2,806 \\
\hline air & 185,00 & 0,480 \\
\hline AVG & 77,083 & 0,20 \\
\hline
\end{tabular}

Rencana untuk komposisi mutu beton K225 menggunakan metode SNI. Dari perhitungan rancangan campuran beton yang didasarkan pada hasil pengujian agregat kasar dan agregat halus, kuat tekan, faktor air semen, kadar air bebas ukuran maksimum, dan nilai slump rencana didapatkan komposisi bahan penyusun beton dengan komposisi dari berat volume beton dapat dilihat pada tabel 4 .

\section{Kekentalan campuran (Slump)}

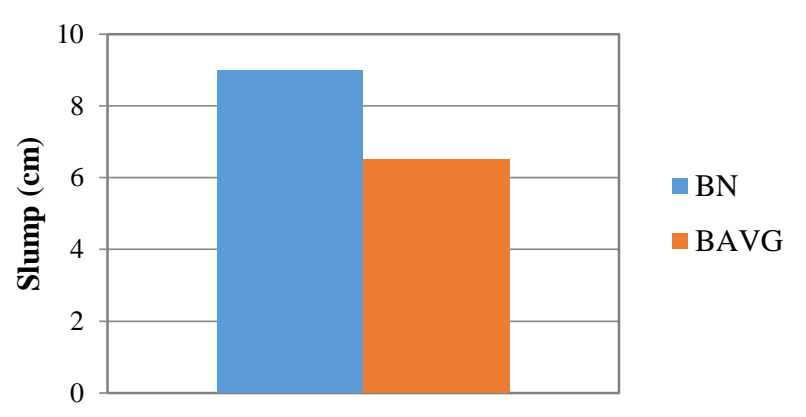

Gambar 2. Perbandingan nilai slump $\mathrm{B}_{\mathrm{N}}$ dan $\mathrm{B}_{\mathrm{AVG}}$

Gambar 2 menunjukan terjadinya penurunan nilai slump akibat penambahan AVG terhadap campuran beton. Slump untuk $\mathrm{B}_{\mathrm{N}}$ sebesar $9 \mathrm{~cm}$ dan $\mathrm{B}_{\mathrm{AVG}} 6,5 \mathrm{~cm}$. Ini menunjukkan bahwa nilai slump menurun seiring dengan ditambahnya AVG kedalam campuran beton. Hal ini disebabkan karena ukuran AVG yang sangat kecil sehingga abu vulkanik dapat menyerap air dengan baik, namum nilai slump masih dalam batas slump rencana yaitu $6-12 \mathrm{~cm}$. 


\section{Kuat Tekan}

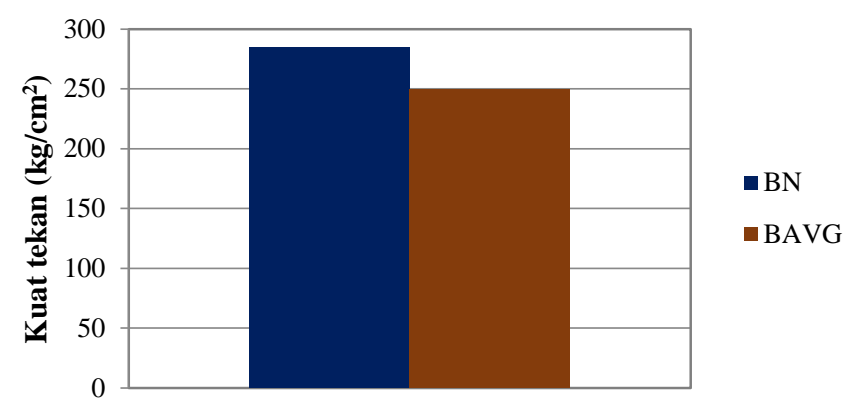

Gambar 3. Kuat tekan umur 28 hari pada $B_{N}$ dan $B_{A V G}$

Gambar 3 menunjukkan bahwa kuat tekan $B_{\text {AVG }}$ lebih tinggi daripada $B_{N}$ yaitu 284,518 $\mathrm{Kg} / \mathrm{cm}^{2}$ sedangkan $\mathrm{B}_{\mathrm{N}}$ sebesar $249,679 \mathrm{Kg} / \mathrm{cm}^{2}$. Disini terlihat terjadi penambahan kekuatan pada $B_{A V G}$ Dengan demikan, di perkirakan pada umur tertentu $B_{A V G}$ akan meningkat kuat tekanya. Pengaruh AVG mengakibatkan terjadi reaksi pengikatan yang dihasilkan dalam proses hidrasi semen oleh silika yang terkandung dalam AVG. Selain itu, butiran AVG yang jauh lebih kecil dari agregat halus membuat beton lebih padat karena rongga antara butiran agregat diisi oleh AVG sehingga dapat memperkecil pori-pori yang ada dan juga memanfaatkan sifat pozzolan dari AVG untuk memperbaiki mutu beton. Penggunaan AVG memperlihatkan dua pengaruh di dalam beton yaitu sebagai butiran halus dan sebagai pozzolan.

\section{Elastisitas}

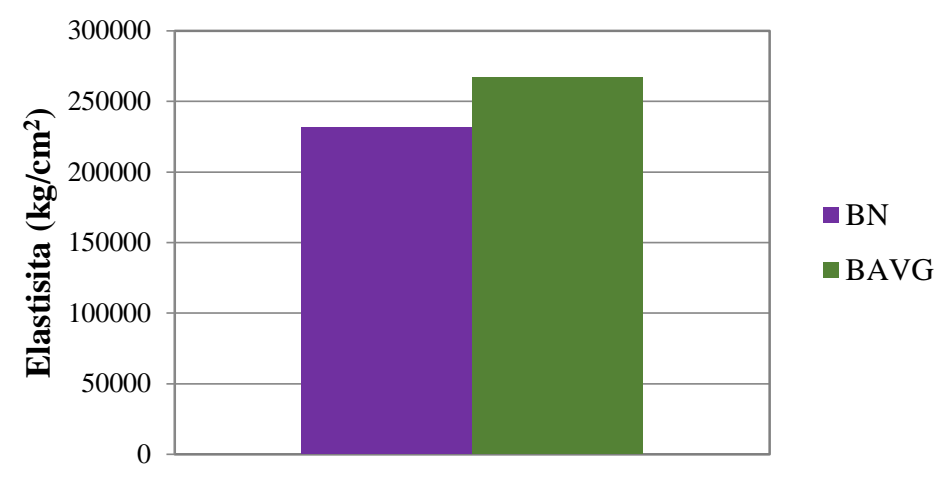

Gambar 4. Elastisitas $B_{N}$ dan $B_{A V G}$

Gambar 4 menunjukan terjadinya kenaikan nilai elastisitas pada beton yang di variasikan AVG. Elastisitas $B_{A V G}$ lebih tinggi daripada $B_{N}$ yaitu sebesar $266978,644 \mathrm{Kg} / \mathrm{cm}^{2}$ sedangkan untuk $B_{N}$ sebesar $231348,364 \mathrm{Kg} / \mathrm{cm}^{2}$. Hal ini membuktikan bahwa penambahan AVG pada adukan beton akan memperbaiki elastisitas. 


\section{Kuat lentur balok}

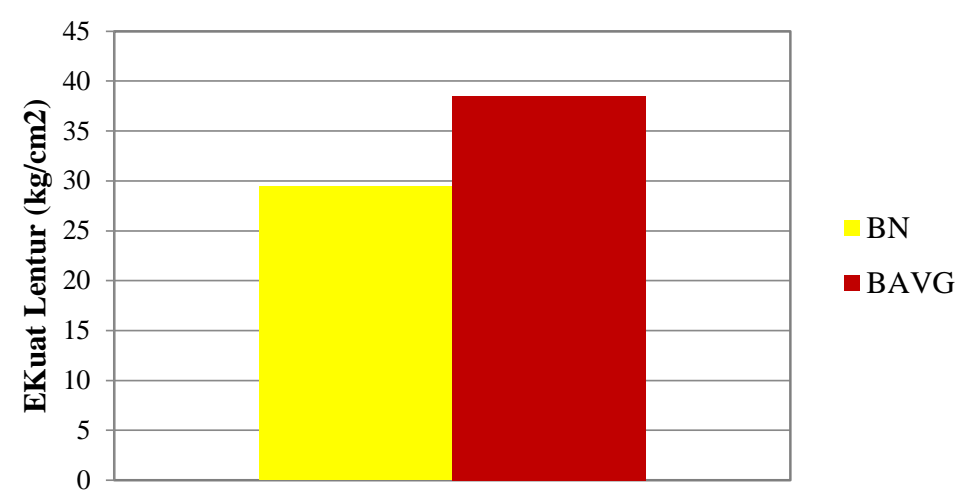

Gambar 5. Kuat lentur balok $B_{N}$ dan $B_{A v G}$

Gambar 5 menunjukkan bahwa kuat lentur benda uji yang menggunakan bahan tambah AVG semakin meningkat dari beton normal. Kuat lentur beton dengan bahan tambah AVG sebesar $38,509 \mathrm{Kg} / \mathrm{cm}^{2}$ sedangkan beton tampa campuran AVG sebesar 29,448 Kg/ $\mathrm{cm}^{2}$. Nilai kuat lentur mengalami peningkatan akibat penambahan AVG dimana AVG memiliki ukuran yang sangat kecil sehingga mampu mengisi pori-pori yang ada pada beton. Akibatnya penambahan kemampuan balok dalam menahan beban (Pmax) lebih besar, maka tentunya akan membuat nilai kuat lentur menjadi lebih meningkat. Hal ini membuktikan bahwa penambahan AVG pada adukan beton memberi pengaruh terhadap kuat lentur di mana akibat penambahan AVG mampu menahan beban yang lebih tinggi.

\section{Hubungan Beban dan Lendutan}

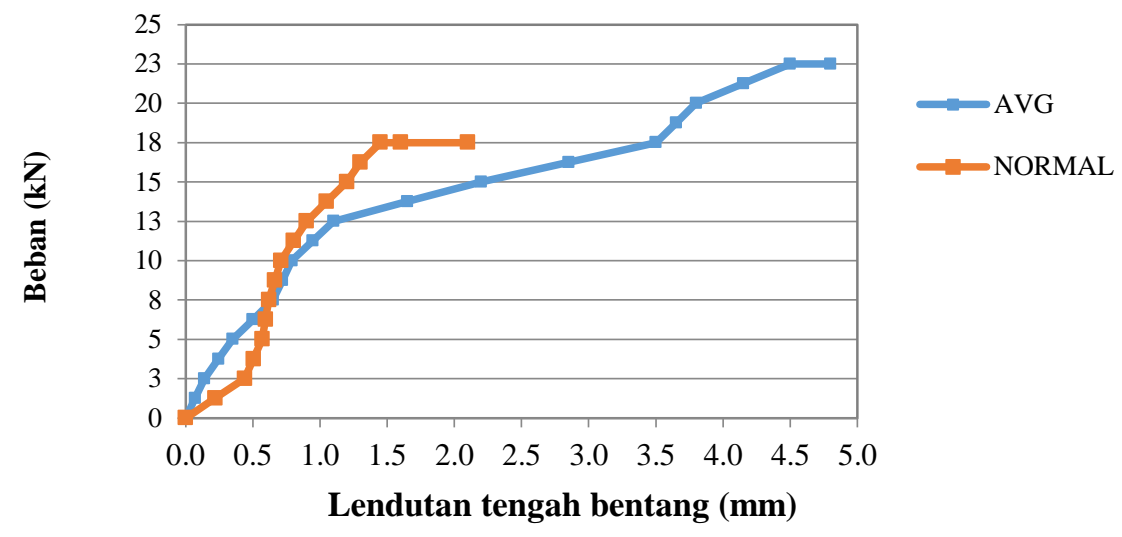

Gambar 6. Hubungan beban-lendutan balok bertulang sampel I

Gambar 6 menunjukkan hubungan beban-lendutan pada tengah bentang balok I. Lendutan maksimum $B_{\text {AVG }}$ sebesar 4,5 mm saat beban maksimal yaitu sebesar 22,5 kN dan mulai terjadi retakan pada balok ketika beban mencapai $12,5 \mathrm{kN}$. Pada $\mathrm{B}_{\mathrm{N}}$ lendutan maksimal sebesar 2,1 mm saat beban maksimum yaitu sebesar $17,5 \mathrm{kN}$ dan mulai terjadi retakan pada beban $10 \mathrm{kN}$. 


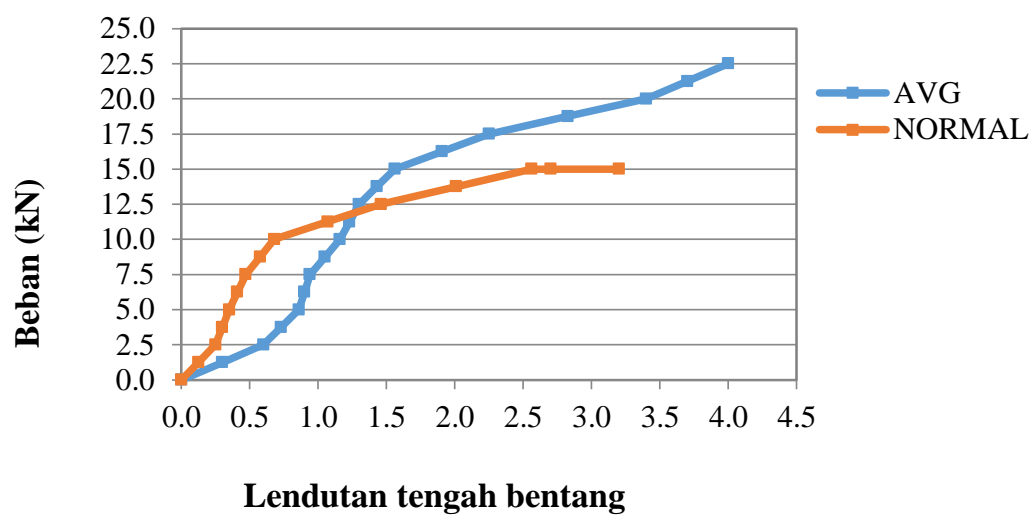

Gambar 7. Hubungan beban-lendutan balok bertulang sampel II

Gambar 7 menunjukkan hubungan beban-lendutan di tengah bentang balok II. Pada $\mathrm{B}_{\mathrm{AVG}}$ lendutan yang terjadi sebesar 3,4 mm saat beban maksimal yaitu sebesar $20 \mathrm{kN}$ dan mulai terjadi retakan pada balok ketika beban mencapai $12,5 \mathrm{kN}$. Pada $\mathrm{B}_{\mathrm{N}}$ lendutan yang terjadi sebesar 3,2 mm saat beban maksimum yaitu sebesar $15 \mathrm{kN}$ dan mulai terjadi retakan pada beban $7,5 \mathrm{kN}$.

Beban-beban yang bekerja pada struktur, baik yang berupa beban gravitasi (berarah vertikal) maupun beban-beban lain, menyebabkan adanya lentur dan deformasi pada elemen struktur. Lentur pada balok merupakan akibat dari adanya regangan yang timbul karena adanya beban luar. Material penyusun sangatlah berpengaruh terhadap lendutan dan deformasi. semakin baik kuat desak dan elastisitas maka semakin baik pula kemampuan deformasi dan lendutannya. Nilai kekakuan balok $B_{A V G}$ sebesar $112631,6154 \mathrm{kN} / \mathrm{cm}^{2}$ dan balok $B_{\mathrm{N}}$ sebesar $97600,0904 \mathrm{kN} / \mathrm{cm}^{2}$. Ini membuktikan penambahan AVG bisa meningkatkan kekakuan balok.

\section{Pola Keretakan}

Berdasarkan hasil pengujian kuat lentur balok, Pola retak saat kondisi runtuh yang ingin dicapai yaitu terjadi retak pada daerah $1 / 3$ bentang tengah dari balok. Pola retak balok beton menghasilkan pola retak yang relatif sama yaitu pada bagian $1 / 3$ bentang tengah sehingga dapat dikatakan bahwa retak yang terjadi termasuk retak lentur. Retak maksimum yang terjadi yaitu pada $1 / 3$ bentang tengah dan menuju beban yang bekerja. Berikut ini disajikan gambar pola keretakan yang terjadi. Sesuai ditunjukkan pada gambar 8 .

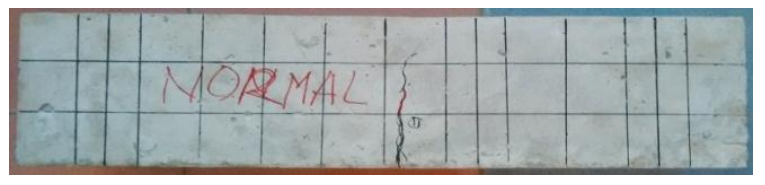

$\mathrm{B}_{\mathrm{N}} 1$

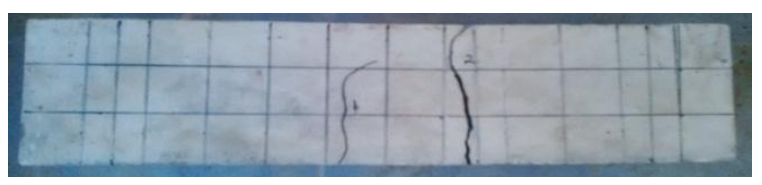

$\mathrm{B}_{\mathrm{AVG}} 1$

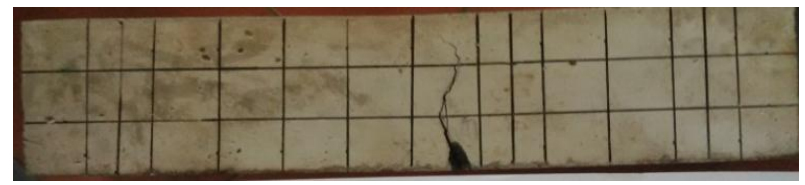

$\mathrm{B}_{\mathrm{N}} 2$

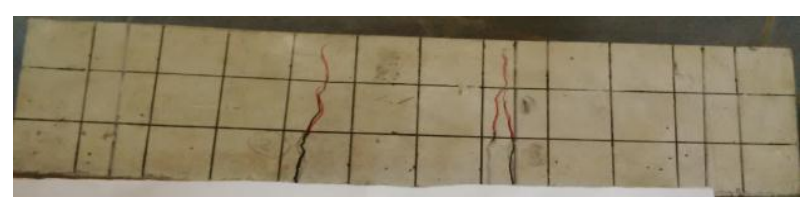

$\mathrm{B}_{\mathrm{AVG}} 2$

Gambar 8. Hubungan beban-lendutan balok bertulang sampel II 


\section{SIMPULAN}

kesimpulan penelitian ini sebagai berikut:

1. Kuat lentur dengan bahan tambah AVG sebesar 20\% lebih kuat dibandingkan dengan beton normal

2. Kuat lentur yang terjadi untuk $B_{N}$ sebesar $29,448 \mathrm{~kg} / \mathrm{cm}^{2}$, setelah divariasikan $20 \%$ AVG terhadap berat semen terjadi kenaikan sehingga menghasilkan kuat lentur sebesar 38,509 $\mathrm{kg} / \mathrm{cm}^{2}$ serta beban ultimit rata-rata $B_{\mathrm{AVG}}$ sebesar $21 \mathrm{kN}$ sedangkan beban ultimit untuk beton normal sebesar $16,25 \mathrm{kN}$.

\section{DAFTAR PUSTAKA}

Al-Zou, J. and K. K. Al-Zboon., 2014, Effect of volcanic tuff on the characteristics of cement mortar. Cerâmica, 60: 279-284.

Astanto, T. B.,2001, Konstruksi Beton Bertulang. Yogyakarta, Kanisius.

Dipohusodo, I. 1999, Struktur Beton Bertulang, Jakarta, PT. Gramedia Pustaka Utama.

Ekaputri, J. J., Triwulan, et al., 2011, Mechanical Properties of Volcanic Ash Based Concrete. Proceedings of International Seminar on Applied Technology, Science, and Arts (3rd APTECS), Surabaya, 6 Desember.

Ibrahiem, E.-S. M. and S. A. M. Ahmed, 2014, Evaluation of Jebel Marra Volcanic Ash as Supplementary Cementitious Material for Use in Blended Cements. IOSR Journal of Engineering Vol. 04 (3):31-37.

Kamang, E. J., I. M. Oyemogum, et al. 2013, Volcanic Ash, Metakaolin and Ordinary Portland Cement Blends in Concrete Production. Central Europe Toward Sustainable Building (CESB13), Prague.

Mulyono, T. 2004, Teknologi Beton. Yogyakarta, Andi Offset.

Nugraha, P. and Antoni. 2007, Teknologi Beton. Yogyakarta, Andi.

Olawuyi, B. J. and K. O. Olusola. 2010, Compressive Strength of Volcanic Ash/Ordinary Portland Cement Laterized Concrete. Civil Engineering Dimension Vol.12 (1) :23-28.

Yasin, A. A., M. T. Awwad, et al. 2012, Effect of Volcanic Tuff on the Concrete Compressive Strength. Contemporary Engineering Sciences Vol. 5 (6) : 295-306. 